\title{
A THEORETICAL MODEL OF STAKEHOLDER PERCEPTIONS OF A NEW FINANCIAL REPORTING SYSTEM
}

\begin{abstract}
This paper proposes a theoretical model to assess how stakeholders perceive a major change of an accounting regime: for example, the adoption of International Financial Reporting Standards [IFRS] or an IFRS-based financial reporting system. Using a theory borrowing approach, the model evolves from a review of key factors that have been reported to affect perceptions of change. These factors are drawn from literature dealing with management change, institutional arrangements, psychology, information systems, sociology and financial reporting. The proposed model implicates individual, technical, situational, and change process factors as major elements. Thereby, it highlights a multiplicity of matters that influence perceptions of a financial reporting change. The emerging model holds strong prospect of improving understanding of change processes in general, and financial reporting changes, in particular. The proposed model can be used to assess how any major national financial reporting reform is (or will be) perceived, and whether or not the reform will be successful. The practical insights arising from application of the model can be particularly relevant for regulators and standard-setters in devising appropriate strategies for coping with perceived implementation problems.
\end{abstract}

Keywords: Accounting, Change, International Financial Reporting Standards, Model, Perceptions.

\section{Introduction}

Mandatory adoption of International Financial Reporting Standards (IFRS) for the preparation of consolidated financial statements of companies listed in the European Union (effective from 2005) triggered widespread adoption of IFRS-based accounting systems by national governments. Such IFRS-based accounting systems are accepted commonly to be of Anglo-Saxon origin. However, some countries (such as France, Portugal, and Japan) have adopted IFRS-based accounting systems in non-Anglo-Saxon contexts. Traditionally, systems of financial reporting in these countries have focused on the needs of creditors, national tax systems, and a Latin-based legal code. In such countries, the adoption of IFRS represented a fundamental change in the way accounting and financial reporting were perceived.

Little attention has been devoted to ascertaining how fundamental changes in financial reporting systems and associated financial statements are perceived by stakeholders (Rees and Chandler, 2004). This is disconcerting because the views of stakeholders regarding the acceptability and implementation of financial reporting standards are crucially relevant. A growing body of change-related literature has acknowledged the importance of understanding how 
individuals perceive the likely success of a change initiative. Dibella (2007, p. 236) aptly points out that

Participant perceptions of change are more critical to successful change implementation than the nature of the change itself. Without the willing or active involvement of participants, change initiatives do not succeed, or they may lead to unintended or counter-productive consequences. Managing participant perceptions is a fundamental element of managing the change itself.

More needs to be known about how stakeholders perceive new financial reporting systems.

In this paper, we develop a multi-factor theoretical model to assist in evaluating stakeholders' perceptions of the financial reporting changes embodied in an IFRS or an IFRS-based model. We develop 22 propositions about factors that influence those perceptions. These are outlined in four categories: individual factors (Propositions 1.1 to 1.9); technical factors (Propositions 2.1 to 2.3); situational factors (Propositions 3.1 to 3.5); and change process factors (Propositions 4.1 to 4.5). All of the propositions advanced "rely on the work of many others ... are supported by references to various theories and research findings ...[and]... though... aimed at empirical testing, none is subjected to empirical testing here" (Gibbins, 1984, p. 104). Individually and collectively, they provide a theoretical tool to comprehend and investigate stakeholders' views regarding financial reporting reforms (e.g., national adoption of an IFRS or IFRS-based model).

Most extant research has adopted a macro-oriented approach to understand change processes, using a variety of theoretical underpinnings. These include institutional theory (DiMaggio and Powell, 1983; Oliver, 1991) and resource dependence theory (Pfeffer and Salancik, 1978). ${ }^{1}$ To a large extent, micro-level theorizing has been absent in institutional analysis, despite its importance in understanding the influence of the subjective perceptions that individuals have of institutional change (Campbell, 2004, p. 187). Neves (2009) recognized the limitations of the macro approach and the need to direct attention to more micro analysis of individual issues influencing change. He called for future theories and research to adopt micro and macro perspectives. We respond to this call by providing a comprehensive theoretical framework encompassing both perspectives.

The model we propose complements financial reporting literature by reviewing literature in other subject areas that has addressed the way change processes are perceived. These include (in approximate order of reliance) psychology, change management, management accounting, organizational behaviour, information systems, and sociology. To the best of our knowledge, the integration of such diverse literature for this purpose is a new methodological development. Such integration enables construction of a comprehensive theoretical model - one that explains stakeholders' perceptions of local adoption of IFRS or an IFRS-based model as a complex and

\footnotetext{
${ }^{1}$ This research has focused predominantly on environmental, organizational, and change process variables (Cunningham, 2006; Oreg, 2006).
} 
evolving process affected by individual, situational, technical and change process factors. The model proposed has the capacity to facilitate understanding of the degree of acceptance, by various interest groups, of the adoption of IFRS or an IFRS-based system. Such receptiveness (or lack of it) is likely to influence whether or not implementation of an IFRS or IFRS-based model will be successful in national jurisdictions. Receptiveness will be a key determinant in achieving accounting information quality goals set by the European Commission, International Accounting Standards Board (IASB) and/or International Public Sector Accounting Standards Board (IPSASB).

The proposed theoretical model will help reveal underlying issues that are likely to hinder national accounting settings from attaining full convergence with IFRS and/or effective adoption of IFRS. It will facilitate discussion of how those issues might be resolved in the future. The model can be applied to explain the reluctance of some European and non-European countries (including the USA) to embrace IFRS or IFRS-based systems. As well, it has strong capability to help develop research instruments for use in survey-based research and field interviews.

The paper proceeds as follows. Section 2 reviews extant research on stakeholders' perceptions of financial reporting. Section 3 explains the theory building approach used and the main assumptions underpinning construction of the proposed model. It outlines two fundamental elements of the proposed model (change processes and perception), describes the general features of the proposed model, and elaborates on the dependent variable. A diagrammatic representation of the model is introduced. The following four sections elaborate on the model's major independent variables: individual factors (Section 4); technical factors (Section 5); situational factors (Section 6); and change process factors (Section 7). Section 8 highlights expected contextual variations of the model. Section 9 summarises findings, presents conclusions, and suggests areas for further research.

\section{Stakeholder groups and empirical research on stakeholders' perceptions}

Three stakeholders' groups are regarded to be the main targets of financial reporting change: users, preparers and auditors. Studies of stakeholders' perceptions of financial statements, and of the adoption of new financial reporting systems, are summarized in Table 1. 
Table 1: Financial reporting literature examining stakeholders' perceptions

\begin{tabular}{|c|c|}
\hline Object of Analysis & Studies \\
\hline Financial Statements & $\begin{array}{l}\text { McKinnon (1984); McNally et al., (1992); Schneider and Gordon (1994); Abu-Nassar } \\
\text { and Rutherford (1996); Ho \& Wong (2001, 2003); Naser and Nuseibeh, (2003a,b); } \\
\text { Naser et al. (2003); Mirshekary and Saudagaran (2005); Son et al. (2006); Cassell et } \\
\text { al. (2013) }\end{array}$ \\
\hline IFRS Adoption & $\begin{array}{l}\text { Watty and Carlson, (1998); Joshi and Al-Basteki (1999); Lin et al. (2001); Joshi and } \\
\text { Ramadhan (2002); Sucher and Jindrichovska (2004), Rees and Chandler (2004); } \\
\text { Jermakowicz (2004); Vellam (2004); Xiao et al. (2004); Mir and Rahaman (2005); } \\
\text { Jones and Luther (2005); Aljifri and Khasharmeh (2006); Jermakowicz and Gornik- } \\
\text { Tomaszewski (2006); McEnroe and Sullivan (2006); Tyrrall et al. (2007); Joshi et al. } \\
\text { (2008); Uyar and Güngörmüsß (2013); Albu et al. (2013a, 2014); Abdullah et al., } \\
\text { (2014); Kiliç et al. (2014); Morris et al. (2014); Phan and Mascitelli (2014) }\end{array}$ \\
\hline $\begin{array}{l}\text { Process of International } \\
\text { Accounting Harmonization }\end{array}$ & Roberts and Salter (1999); Glaum (2000); Naser et al. (2005) \\
\hline EU Accounting Directives & Blake et al. (1999) \\
\hline True and Fair view' concept & Kirk (2006); Albu et al. (2013b) \\
\hline
\end{tabular}

Reading of the literature cited in Table 1 leads to a conclusion that more needs to be learnt about stakeholders' perceptions regarding the adoption of new financial reporting systems (such as IFRS-based systems). This is because most previous research has had a limited focus on the relationship between perceptions of new financial reporting systems and only one (or a few) factors, such as environmental factors (e.g., McEnroe and Sullivan, 2006) or technical factors (e.g., Lin et al., 2001, Watty and Carlson, 1998). Additionally, much prior research has neglected the role of some other factors that are influential in formatting and developing an individual's perceptions (e.g., behavioural matters).

The shortcomings of extant research on stakeholders' perceptions of financial reporting processes has motivated us to search for broader-ranging literature on perceptions of change processes - such as in psychology, change management, management accounting, organizational behaviour, information systems, and sociology. Literature from these streams was integrated with the existing literature on financial reporting change to develop a fuller understanding of financial reporting systems change processes.

\section{Theory building and perception}

\subsection{Borrowing Approach}

Current financial reporting literature (our "domestic" literature) lacks an established theoretical framework or cumulative research tradition that can be used to explain stakeholders' perceptions of financial reporting processes. As a way forward, we develop a theoretical model through a "theory borrowing" approach: that is, we import concepts or theories that explain a phenomenon in a specific research field outside of our discipline (these are so-called "travel" or "borrowed" theories) (Oswick et al., 2011). 
The need for theory development in accounting has long been recognized. Laughlin (1995, p. 83) claimed that accounting theory will never have an unquestionable and guaranteed theory (like a theory of gravity) that is susceptible of generalizations. Because accounting is a social practice - a social science - it must be studied within broader economic, social and political contexts. Accounting is not an objectively neutral set of measurement techniques (Miller and O'Leary, 1987; Miller, 1994; Laughlin, 1995; Humphrey and Scapens, 1996). It must be understood in terms of "its interrelation with other projects or the social and organisational management of individual lives" (Miller and O’Leary 1987: 235).

The quest to understand accounting and financial reporting by organizations and within societies has generated a stream of "theory borrowing" from other disciplines (for example, by Walker, 1987; Power, 1992; Walker and Robinson, 1994; Laughlin, 1995; Fogarty, 1998). The benefits of theory borrowing have been recognized widely (Hambrick, 2007; Corley and Gioia, 2011; Corbett et al., 2014). Theory borrowing has promoted strong links between organizational and management studies, and broader social science disciplines. It has improved the multidisciplinary richness of fields of study (Agarwal and Hoetker, 2007; Whetten et al., 2009; Corley and Gioia, 2011). Theory borrowing can be particularly valuable in young fields to enhance their legitimacy, since borrowed theories "...allow a nascent discipline to 'project' itself as scientific" (Kenworthy and Verbeke, 2015, p. 183). Theory borrowing can also improve the quality of theory-based research, since systematically applying a theory in different settings enhances its explanatory power by delineating contextual differences (Whetten, 2009).

\subsection{Perception}

Gordon (1993, p. 31) defined perception as an active process "by which each person senses reality and comes to a particular understanding." She emphasized that "different people hav[e] different, even contradictory, views and understandings of the same event or person." Thorough understanding of perception requires comprehension of the physical world, and the characteristics of perceivers (Sekuller and Blake, 1994). To develop a comprehensive understanding of individuals' change-related perceptions, different disciplinary knowledge must be combined, using multi-level analysis (micro and macro). Additionally, there is a need to focus on internal and external aspects of change, particularly the interactions between them (Sinatra, 2002).

An in-depth assessment of individuals' perceptions of change initiatives will help to identify potential obstacles to change (Jermias, 2001). This will assist change agents (principally those responsible for implementing change initiatives, such as regulators) to devise strategies to foster acceptance of a change initiative by "change targets". Acceptance by the latter is crucial in determining whether a change effort will succeed or fail (Jimmieson et al., 2009). Campbell (2004) emphasized the relevance of change targets' perceptions of the success of change actions, noting that 
... what links macro-level conditions to outcomes are individuals (or group of individuals) acting at the micro-level in response to their social and institutional situations and to each other ... Poor understanding of the perceptual process is one reason why many institutionalists, including rational choice theorists, have turned recently to cognitive and social psychology for insights ... a particularly promising theoretical avenue emphasizes how patterns of interaction affect how actors perceive and define their situations. (p. 117)

Considerable research in management accounting and Management Information Systems (MIS) has argued that an information system is perceived favourably when it is accepted and used (Igbaria et al., 1995) or when it increases user satisfaction (Kanellou and Spathis, 2013). However, when adoption of a system is obligatory (as with IFRS or IFRS-based systems) use is not an appropriate proxy in evaluating the perceptions of individuals.

Shields (1995) measured success in implementing an Activity Based Costing (ABC) system by assessing managers' perceptions of the different role of ABC systems. Anderson (1995) used the concept of perceived value to assess individuals' perceptions of the success of an ABC system. This was derived from the Value-based Model - a theory of consumer choice and decision making which draws on cost-benefit analysis principles. Broadly, it defines perceived value as the difference between perceptions of total benefits and total costs/sacrifices. Perceived value is "a context specific perception that may drive user attitudes and behaviors" (Turel et al., 2007, p. 65). The Value-based Model posits that the level of perceived value affects the level of intent to support a new system. Importantly, this implies the assumption of a broader view of value - one that includes monetary, emotional, mental, environmental, economic, cultural, and performance factors (Turel et al., 2007).

Drawing on the Value-based Model, we propose that perceived value be the dependent variable measure of individuals' perceptions of a new financial reporting system (e.g., principlesbased IFRS). Consequently, the concept of perceived value reflects whether an individual supports an adoption decision - after a (usually implicit) comparison of benefits and costs/sacrifices. The concept of perceived value reflects stakeholders' perceptions of the positive or negative value of a new financial reporting system. This implies that an individual will hold positive perceptions of a new system (and will be prone to support it) if (s)he believes that the benefits of adopting the new system exceed the inherent costs/sacrifices. Thus, the perceived value concept compares the "give" and "take" components of the new financial reporting system. Overall, an individual's support is based on a broad range of value tradeoffs that form an assessment of value. For example, even if IFRS-based standards are believed to provide relevant and useful information, individuals could have a low overall perception of value, leading to low support. They may hinder the change process 
when the adoption of IFRS or IFRS-based standards seems too expensive or difficult to implement in a national context (when contrasted with its benefits).

The proposed model hypothesizes a relationship between stakeholders' perceived overall value of a new financial reporting system (dependent variable) and four broad categories of independent variables: individual, situational, technical and change process-related. As with Jarrar et al. (2007), we argue that the perceptions of individuals influence their behaviours and whether or not a new financial reporting system is implemented successfully. Figure 1 represents the model diagrammatically. Below, we elaborate on the overall content and logic of the model, describe its core elements and underlying rationale, and provide an overview of the literature pertaining to each major element.

Figure 1. Theoretical basis for assessing how individuals perceive a new financial reporting system

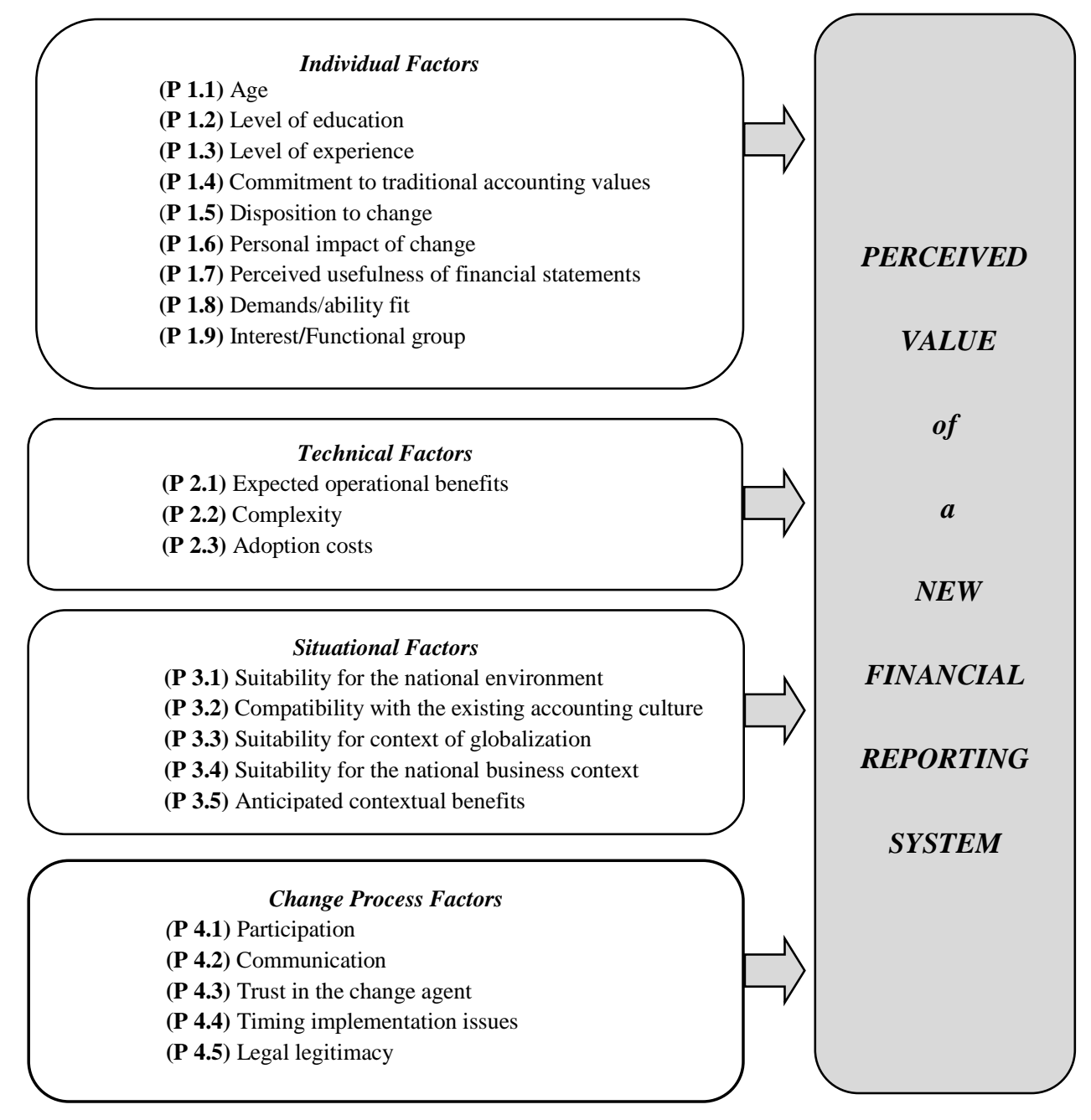

In the borrowing approach used to develop this model, "travel theories" complemented the financial reporting literature ("domestic theory"). In Table 2 travel theories are grouped in four areas (change, psychology, management accounting and MIS, institutional theory). The closest 
imported literature to the financial reporting field was from management accounting and MIS. The literature in this field featured an abundance of quantitative/positive research addressing hypotheses regarding the factors that explain individuals' perceptions of the adoption of new information systems. The lack of strong and comprehensible theoretical support in this literature led us to search for literature related to the concepts of perception (in psychology) and change processes (in change and change management literature). These complementary streams of literature helped to provide a theoretical base from which to develop a model of factors influencing perceptions of change initiatives.

Despite persistent reference to institutional theory in the development of our model, some of the borrowed insights have already been used in the financial reporting literature on change processes. In other instances, institutional theory has also represented a travel theory in this borrowing process, especially in developing some "individual" propositions and "change process" propositions. To the best of our knowledge, these institutional insights (whether domestic or not) have not yet been used to study the specific phenomenon of stakeholders' perceptions of change initiatives. Our contribution in importing this knowledge is to advance the study of stakeholders' perceptions of change processes.

Table 2: Theory building approach

\begin{tabular}{|c|c|c|}
\hline & Literature & Contribution \\
\hline \multirow{4}{*}{ Travel Theories } & Change & $\begin{array}{l}\text { P1.1; P1.2; P1.6; P1.8; P1.9; } \\
\text { P2.1; P2.2; P3.1; P3.2; P3.3; } \\
\text { P3.4; P4.1; P4.2; P4.3 }\end{array}$ \\
\hline & Psychology & $\begin{array}{l}\text { P1.1; P1.2; P1.4; P1.5; P1.6; } \\
\text { P1.8; P1.9; P3.1; P3.2; P3.3; } \\
\text { P3.4; P4.1; P4.2; P4.3; }\end{array}$ \\
\hline & $\begin{array}{l}\text { Management accounting and MIS (mostly } \\
\text { empirical evidence) }\end{array}$ & $\begin{array}{l}\text { P1.1; P1.2; P1.3; P1.4; P1.5; } \\
\text { P1.6; P1.8; P1.9; P2.1; P2.2; } \\
\text { P4.1; P4.2 }\end{array}$ \\
\hline & Institutional theory & P1.4; P1.9; P4.1; P4.2; P4.3 \\
\hline \multirow{2}{*}{ Domestic Theories } & Financial reporting (empirical evidence) & $\begin{array}{l}\text { P1.3; P1.6; P1.7; P1.9; P2.1; } \\
\text { P2.2; P2.3; P3.1; P3.2; P3.3; } \\
\text { P3.4; P3.5; P4.4 }\end{array}$ \\
\hline & $\begin{array}{l}\text { Financial reporting (based on institutional } \\
\text { insights) }\end{array}$ & $\begin{array}{l}\text { P1.6; P2.1; P2.2; P3.1; P3.2; } \\
\text { P3.3; P3.4; P3.5; P4.1; P4.2; } \\
\text { P4.3; P4.4; P4.5. }\end{array}$ \\
\hline
\end{tabular}

As can be seen from Table 2, travel theories have had a crucial role in constructing our model. They improve understanding of perceptions and change processes in the specific context of financial reporting (domestic literature). They have been valuable in providing theoretical support for the domestic literature.

\section{Individual Factors}

A growing literature on management change concludes that human factors affect the success of change efforts (Walker et al., 2007; Rafferty et al., 2013). Consistent with these conclusions and the theoretical insights they provide (Gordon, 1993), we explain the way individuals perceive 
things, and their consequent behaviour, by the following personal characteristics: age, level of education and experience, commitment to traditional accounting values, disposition to change, personal job impact of the change, perceived usefulness of financial statements, demands/ability fit, and functional group. Each of these characteristics is discussed below.

(i) Age

Older people have been found to be more likely than younger people to resist change (Zmud, 1979). This is attributed to the decline with age of intellectual abilities and openness to new experiences (Kanfer and Ackerman, 2004), rendering it more difficult for older people to process new information or to learn new skills. Older people are less change-oriented than younger people and they need support to adapt to change (Caldwell et al., 2004). Thus, we expect younger individuals will perceive new financial reporting standards more favourably than older individuals. We propose that:

P 1.1: Individuals' perceptions of the value of a new financial reporting system decrease with their age.

\section{(ii) Level of education}

The receptivity of individuals to change is associated with their level of education (Zmud, 1979; Anderson, 1995). Well-educated individuals are reported to have better adaptive response patterns to changing job demands (Heggestad and Kanfer, 2000). Thus, we expect that individuals with higher levels of education will adapt better to new financial reporting standards and perceive them more favourably.

P 1.2: Individuals' perceptions of the value of a new financial reporting system increase with their level of education.

\section{(iii) Level of experience}

Research in MIS has reported consistently that the experience individuals have had with an information system reinforces the likelihood of its acceptance (Zmud, 1979; Igbaria et al., 1995). In the accounting literature, some studies report a positive association between level of experience and an individual's perception of a new system (e.g., Anderson, 1995). ${ }^{2}$ Other studies find a negative association (e.g., Hicks, 1978). In view of contradictory empirical evidence, the following proposition is non-directional.

\footnotetext{
${ }^{2}$ In the context of IFRS, the Big 4 international accounting firms have a high level of experience and support national adoptions of IFRS (Irvine, 2008). Accounting professionals trained in IFRS (especially those working for Big 4 accounting firms) have had a positive impact on knowledge of IFRS standards (Uyar and Güngörmüş, 2013).
} 
P 1.3: Individuals' perceptions of the value of a new financial reporting system are related to their level of experience.

\section{(iv) Commitment to traditional accounting values}

Prior research suggests a negative relationship between the commitment of individuals to an existing financial reporting system and the way they perceive a new system. Building on the theory of cognitive dissonance, ${ }^{3}$ Jermias (2001) reported that individuals' judgments about the usefulness of new cost accounting systems were influenced negatively by their commitment to an existing system. Drawing on this, we expect that the commitment of individuals to an existing financial reporting system is associated strongly with the power of the existing system (or prevailing institutions) to affect their accounting-related context. This is reflected by the extent to which existing accounting values are embedded in the thoughts of individuals.

P 1.4: Individuals' perceptions of the value of a new financial reporting system are related to their level of commitment to traditional accounting values.

\section{(v) Disposition to change}

Numerous studies of organizational change, MIS change, and management accounting change (for example, by Anderson, 1995; Marinova et al., 2015) have found that the disposition of individuals to change influences their perceptions of a change initiative. Judge et al. (1999, p.107) concluded that the success of a change initiative lies "within the psychological predispositions of individuals experiencing the change." Thus, the different innate inclinations of individuals to adopt change has strong potential to predict their attitudes towards specific change (Oreg, 2006). The change literature identifies some personality traits that influence specific change-related behaviours (Oreg, 2006; Holt et al., 2007). These include optimism, altruism, tolerance for ambiguity, psychological resilience, and routine/sensation seeking. We expect that the disposition of individuals to change (derived from personality traits) is likely to affect their perceptions of a new financial reporting system.

\footnotetext{
${ }^{3}$ Bem (1967, p. 183) defined the theory of cognitive dissonance as follows: "If a person holds two cognitions that are inconsistent with one another, he will experience the pressure of an aversive motivational state called cognitive dissonance, a pressure which he will seek to remove, among other ways, by altering one of the two 'dissonant' cognitions". For Jermias (2001, p. 144), the theory of cognitive dissonance "provides discerning and testable hypotheses of why people are influenced by their prior beliefs and why they are motivated to resist change." Jermias (2001, p. 146) explained this linkage between cognitive dissonance and resistance to change: "Dissonance theory argues that people's estimates of the state of the world are not independent of their own state of beliefs....people's subsequent decisions are very much influenced by their initial beliefs. To reduce their cognitive dissonance, people try to seek information that is consistent with their prior beliefs. Consequently, belief-confirming information will be weighted more favorably than belief-disconfirming information". Jermias' study (2001) reported that when individuals are committed to an existing system, they will downgrade the potential benefits of the new system, causing them to be more resistant to change.
} 
P 1.5: Individuals' perceptions of the value of a new financial reporting system are related to their disposition to change.

\section{(vi) Personal impact of change}

Research in organizational change and management accounting has yielded substantial evidence that individuals' perceptions of a change are influenced by the impact of the change on them personally (e.g., Fedor et al., 2006; Armenakis et al., 2007; Neves, 2009). Often, the adoption of change initiatives results in job loss, job conflicts, or reduced job status (Walker et al., 2007). These factors constitute the rational self-interest assumption underpinning expectancy theory (Vroom, 1995) and behaviour decision theory (Shafir and LeBoeuf, 2002). Such theories assume that under conditions of lower utility and/or valence outcomes, individuals reduce efforts, affecting the way they perceive change (Meglino and Korsgaard, 2004).

Thus, we expect individuals who believe that reward contingencies are associated with successful implementation of change (for example, a new regime of financial reporting standards) are likely to be supportive. We posit that the personal impact of change can be assessed as the consequences of adoption of the new system on an individual's job; and in terms of the extent to which the new system satisfies an individual's needs.

Impact on an individual's job: Holt et al. (2007) and Rafferty et al. (2013) suggested four types of job outcomes will influence the way individuals evaluate a change initiative: performance, security, power, and prestige. Intrinsic job rewards of autonomy, power and prestige are also likely to be influential. Accordingly, we expect that individuals will perceive a new financial reporting system favourably if they believe it will have positive job outcomes for them.

Satisfaction of an individual's information needs (exchange legitimacy): The primary objective of financial reporting is to provide decision-useful financial information to stakeholders. The way stakeholders perceive financial reporting change is explained partly by the extent to which financial statements satisfy their specific needs. Thus, it is necessary to specify, in detail, the information needs of various stakeholder user groups (Mirshekary and Saudagaran, 2005). This will help determine the extent to which general-purpose information can satisfy the diverse objectives and needs of stakeholders.

The satisfaction of individual needs is a form of pragmatic legitimacy, known as exchange legitimacy. It represents "support for an organizational policy based on that policy's expected value to a particular set of constituents..." (Suchman, 1995, p. 578). This form of pragmatic legitimacy is related to individuals' perceptions of the usefulness of financial statements, and to the capacity of financial statements produced by a new financial reporting system to serve their specific interests 
(Durocher et al., 2007). Hence, if a user perceives that the proposed system serves their interests, (s)he will confer exchange legitimacy on the process and on the financial reporting standards.

P 1.6: Individuals' perceptions of the value of a financial reporting system are related to the personal impact of the new financial reporting system on their job and on satisfaction of their individual needs.

\section{(vii) Perceived usefulness of financial statements}

User acceptance of information systems is driven largely by perceived usefulness (Igbaria et al., 1995). Several studies have assessed stakeholders' perceptions of the importance of financial statements (e.g., Naser et al., 2003; Son et al., 2006). They suggest that an individual's view of the importance of financial information affects his/her perceptions of proposed standards. Accordingly, we establish the following non-directional proposition:

P 1.7: Individuals' perceptions of the value of a new financial reporting system are related to the importance they attach to financial statements.

\section{(viii) Demands/ability fit}

The extent of the match between an individual's abilities and new job demands accompanying a change initiative, helps to explain an individual's change-related perceptions. Theoretical and empirical research supports the view that individuals' capacity to adopt (or cope with) a new system (e.g., to exercise professional judgment in applying principles-based IFRS) influences their opinions regarding adoption (Cunningham, 2006; Halbouni and Nour, 2014). ${ }^{4}$

P 1.8: Individuals' perceptions of the value of a new financial reporting system are related to their capacities to implement change.

\section{(ix) Interest/Functional group}

A further factor explaining differences in individuals' perceptions of change is the influence of the social/functional group to which an individual belongs. A considerable body of research reports that the influence of norms, values and group behaviour hinders or facilitates the adoption of innovations (e.g., Neves, 2009). Armenakis et al. (2007) identified "principal support" as one of five sentiments affecting individuals' support for a change initiative. This term was used to capture individuals' beliefs regarding the level of support for change that was held by change leaders and

\footnotetext{
${ }^{4}$ Hicks (1978) reported that CPAs perceived accounting innovations less favourably than accounting academics. CPAs had reservations about their ability to perform successfully in subjective non-financial areas. These fears affected their perceptions of the need to adopt accounting innovations.
} 
other respected peers. Therefore, individuals' behavioural support is more likely to occur when there is normative support from the reference group to which they belong.

Institutional theory can enhance explanation of the effect social groups have on the differing perceptions of individuals to change. The conflicting demands of institutional actors increase the likelihood of resistance, since they tend "to fragment generalized belief systems and the intersubjective and shared definition of institutional reality to which institutional theorists attribute such causal force in bringing about uniformity" (Oliver, 1991, p. 163). Accordingly, a lack of consensus among interest/stakeholders groups regarding the adoption of a new financial reporting system is a sign of resistance. Prior research in accounting has suggested that "system effects" hinder or facilitate the rate of change and adoption of innovation (Hicks, 1978; McGowan, 1998). Specifically, Albu et al. (2013) reported different perceptions among stakeholder groups in the Czech Republic, Hungary, Romania and Turkey regarding the adoption of IFRS. Similarly, Qualgli and Paoloni (2012) reported significant differences of opinion among users and preparers in European countries regarding the acceptance of IFRS for Small and Medium Sized Entities (SME). Overall, these findings suggest that managing change requires consideration of the specific interests of the various target groups involved in the change (Carnall, 2007). We advance the following non-directional proposition:

P 1.9: Individuals' perceptions of the value of a new financial reporting system vary among the different accounting interest groups.

\section{Technical Factors}

Technical factors are important determinants of success in implementing any innovation (McLaren et al., 2016). Recognition of the technical limitations of institutionalized rules fosters openness to change (Seo and Creed, 2002; Burns and Baldvinsdottir, 2005). The systems quality of change processes is also crucial to implementation success (Delone and McClean, 1992). This has been reinforced empirically by Kanellou and Spathis (2013), Halbouni and Nour (2014), and McLaren et al. (2016). In the context of international accounting, higher quality standards and higher quality financial statements are claimed to be likely to arise from national adoption of an IFRS-based model (Barth et al., 2008; Joos and Leug, 2012). ${ }^{5}$

A form of legitimacy identified by Suchman (1995) is particularly pertinent: consequential legitimacy. This implies that "the technical properties of outputs are socially defined and do not exist in some concrete sense that allows them to be empirically discovered" (Suchman, 1995, p. 850; see also Meyer and Rowan, 1977, p. 55). Organizations can gain consequential legitimacy by

\footnotetext{
${ }^{5}$ However, a recent review of research of the effects of IFRS on the quality of financial reporting information by Bruggemann et al. (2013) concluded that despite empirical evidence documenting quality improvements from the adoption of IFRS, such evidence is not uniformly positive.
} 
adjusting their goals to moral criteria, such as efficiency, accountability, confidentiality, and reliability. Durocher et al. (2007) suggested that consequential legitimacy is related to a user's perception of a standard setter's pursuit of public interest. Thus, if an individual perceives that the public interest is a concern in the standard-setting process, (s)he will grant consequential legitimacy to the process, affecting his/her perceptions of the proposed standards.

Adoption costs also influence individuals' perception of a major financial reporting reform (Morris et al., 2014; Kiliç et al., 2014; Phan and Mascitelli, 2014). The level of monetary costs is a potential problem inherent in adoption of IFRS. For many countries, IFRS are too complicated and expensive for SMEs - especially the standards dealing with financial instruments, fair value and impairment (Rodrigues and Craig, 2007).

Technical factors should include individuals' assessments of the technical benefits, complexity, and the costs of adoption of the new financial reporting system.

P 2.1: Individuals' perceptions of the value of a new financial reporting system increase with the expected operational benefits of the IFRS model.

P 2.2: Individuals' perceptions of the value of a new financial reporting system decrease with the perceived complexity of the IFRS-based standards.

$P$ 2.3: Individuals' perceptions of the value of a new financial reporting system decrease with the perceived costs of adopting the new financial reporting system.

\section{Situational Factors}

The relevance of situational factors in determining individuals' perceptions to change, and in indicating the likely success of change, has been acknowledged widely (Neves, 2009; McLaren et al., 2016). Such factors include the:

- national attributes of the environment where the change initiative is implemented (internal environment factors);

- broad external competitive environment (external environment factors);

- organizational circumstances under which a change occurs (organizational factors); and

- expected national and organizational benefits arising from the change (anticipated contextual benefits).

Each of these factors is discussed below.

\section{Internal environment factors - national environment and existing culture}

A growing body of literature emphasizes the crucial role of internal environment factors in implementing change successfully (Walker et al., 2007). Changes should be planned and implemented to fit with the national context (Armenakis et al., 2007). Thus, change agents (such as national standard-setters) must ascertain the need to adjust the content of a change initiative (e.g., 
adoption of IFRS) to the national context. Armenakis et al. (2007) suggest that adequacy of perceived change to the local context influences individuals' willingness to support change.

The effect of environment factors on change efforts is acknowledged implicitly by institutional theory. Meyer and Rowan (1977), DiMaggio and Powell (1983), and Campbell (2004) contend that the success of change initiatives is constrained by local institutional contexts. A common argument is that divergence by national institutions is an important determinant of variation across countries in political and economic performance (Campbell, 2004, p. 7). In particular, the extent of institutional change is influenced by the capacity of national collective identity and cultural framing to accept new practices. Consistent with such a perspective, a growing stream of international accounting literature has criticised the suitability and relevance of applying one set of global financial reporting standards to national environments (e.g. Fox et al., 2013; Phan and Mascitelli, 2014. See also Hamid et al., 1993). ${ }^{6}$

The opinions individuals have of IFRS-based standards are influenced strongly by the perceived adequacy of IFRS for their national environment; and by the perceived suitability of IFRS to the national accounting culture.

P 3.1: Individuals' perceptions of the value of a new financial reporting system are related positively to the perceived suitability of IFRS underlining principles to the national environment.

P 3.2: Individuals' perceptions of the value of a new financial reporting system are related positively to the perceived compatibility of IFRS-based standards to the national accounting culture.

\section{External environment factors -the context of globalization}

The change literature has long recognized the effect of the broad external environment on individuals' perceptions of change. The external environment is affected principally by globalization factors, such as competitive demands, and legislative and technological advances (Halbouni and Nour, 2014; McLaren et al., 2016). Globalization pressures are reflected in competitive isomorphism and the convergence of national financial reporting systems. Thus, Borbély and Evans (2006) and Albu et al. (2014) contend that the strength of demands for international financial reporting convergence triumph over the power of the local environment.

P 3.3: Individuals' perceptions of the value of a new financial reporting system are related to the perceived global suitability of the underlining principles of IFRS.

\footnotetext{
${ }^{6}$ There is also evidence suggesting that IFRS are unsuitable for developing countries, or countries whose national accounting culture is not Anglo-Saxon or Anglo-American. Chand (2005) noted that without local adjustments, financial reporting standards prepared for developed countries are unsuitable for emerging economies. Such arguments suggest that national culture, which is embedded strongly in financial accounting, is likely to cause problems in applying IFRS, even if market and political forces strive for international convergence.
} 
Organizational factors - the national business context

Particular organizational circumstances exert a powerful influence on individuals' beliefs, attitudes and behaviours (Self et al., 2007). Thus, organizational factors are a further set of variables of interest in evaluating the effectiveness of change (Halbouni and Nour, 2014; McLaren et al., 2016). The success of change depends on the extent to which the change initiative fits the organizational environment. Such arguments are embedded in institutional theory: organizations are more likely to conform to institutional norms when these norms are compatible with their interests (Oliver, 1991). The adoption of new rules is influenced by how an organization relates to its environment: that is, by the consistency of institutional rules with the organization's goals and culture.

The influence of a firm's operating circumstances on financial reporting practices has been well documented: for example, that the adoption of IFRS, and extent of compliance with IFRS, is associated with corporate characteristics (e.g., size, listing status, internationality) (Guerreiro et al., 2012; Christensen et al., 2015).

P 3.4: Individuals' perceptions of the value of a new financial reporting system are associated with the perceived suitability of IFRS-based standards for the national business context.

\section{Anticipated contextual benefits}

Adoption of IFRS usually brings contextual benefits (operational, financial, and in terms of legitimacy). Operational benefits arise from technical improvements in the financial reporting system. Financial benefits are associated mainly with reduced cost of capital (Joos and Leung, 2013), better integration of national and international financial markets (Covrig et al., 2007), increased economic growth (Jaruga et al., 2007), enhanced international credit-ratings (Tyrrall et al., 2007), and reduced costs of processing financial information for international capital markets (Hope et al., 2006).

Institutional practices (such as IFRS) can be adopted to achieve external legitimacy, regardless of their actual usefulness. Indeed, the financial reporting literature contains strong argument that adoption of IFRS is likely to result in important legitimacy benefits. These include enhanced reputation of national companies (Guerreiro et al., 2012; Alon, 2013; Albu et al., 2014), legitimacy and social acceptability from other countries (Rodrigues and Craig, 2007), and enhanced status of professional accounting bodies (Guerreiro et al., 2015).

We expect perceptions of a new financial reporting system will be more favourable if individuals believe that adoption will result in contextual benefits (operational, financial, legitimacy). Under these circumstances, they are less likely to develop feelings of resistance. 
P 3.5: Individuals' perceptions of the value of a new financial reporting system are related positively to the perceived contextual benefits arising from the adoption of the new financial reporting system.

\section{Change Process Factors}

Change process factors include the processes and the strategies of the change agent to implement a change initiative (Armenakis and Bedeian, 1999; Cullen et al., 2014). A considerable body of research has emphasized the relevance of these factors on how individuals perceive a change effort, as well on the successfulness of a change (Neves, 2009; Georgalis et al., 2015; McLaren et al., 2016).

The extent of the institutionalization of new rules depends on the capacity of change agents to fit those rules and their consequences to a local institutional context, and to mobilize political support from interest groups and key institutional leaders (Campbell, 2004; Scott, 2010). Recent institutional developments show the relevance of national standard-setters in undertaking power strategies to influence constituents' perceptions of the legitimacy of a new financial reporting system. Countries such as the USA have the cultural and economic power to sustain a view that the perceived value of IFRS for the USA is negative; and that FASB standards are more suitable than IFRS for the USA. The change process factors discussed below are likely to influence individuals' perceptions: participation, communication, trust in the change agent, timing of implementation, and legal legitimacy.

\section{Participation}

Participation is often a change agent tactic to influence the beliefs of potential opponents to change. It is a means to create a suitable environment for change by reducing uncertainty, promoting perceptions of fairness, and developing a favourable disposition to a proposed change (Bordia et al., 2004).

Change agents can generate legitimacy of a proposed change by including representatives of an individual's interest group in decision-making structures (influence legitimacy); fostering an open debate and justifying final decisions (procedural legitimacy); allowing adequate representation of various interest groups in the standard-setting process (structural legitimacy); and creating advisory committees (structural legitimacy). Structural legitimacy refers to a moral evaluation of an organization based on its structural characteristics (Suchman, 1995). An organization that adopts socially-accepted structures (by allowing adequate representation of all constituencies, creating consultative committees) can condition individuals' support for a proposed change initiative.

P 4.1: Individuals' perceptions of the value of a new financial reporting system increase with the perceived fairness of the change process. 


\section{Communication}

Effective communication is crucial to the success of change initiatives (Georgalis et al., 2015; Marinova et al., 2015). Communication can involve announcing and explaining change, creating awareness of the need for change, increasing understanding of a proposed change, and minimizing the uncertainty likely to be experienced by change targets (Cullen et al., 2014; Genkova and Geher, 2016).

Some studies in accounting of the use of communication as a power tactic to influence individuals' perceptions have illustrated the discursive nature of accounting and how it can be shaped (e.g., Miller \& O’Leary, 1994; Rose \& Miller, 1992; Young, 1996, 2003; Power, 1997; Potter, 2002, 2005). Rodrigues and Craig (2007, p. 744) highlighted the power of discourse in the success of the international accounting convergence process as follows:

Knowledge about 'true' and 'accurate' financial reporting, produced by the IASB, is alleged to become power through discourse when the largest accounting firms, the EU, and other parties, are disposed to accept, as a taken-for-granted fact, that accounting will be better if it arises from common globally accepted accounting standards.

P 4.2: Individuals' perceptions of the value of a new financial reporting system are related to the perceived quality of the change communication.

\section{Trust in the change agent: personal (including team) legitimacy}

There has been growing interest in the role of trust in the success of change initiatives (Georgalis et al., 2015; Genkova and Geher, 2016). Trust reflects the essence of Suchman's (1995) concept of "personal legitimacy" and its association with the charisma of organizational leaders. In this regard, Weber, writing in 1978 (p.266), asserted that a "charismatically qualified, and hence legitimate person" plays an important role in disrupting old rules, and in institutionalizing new rules (see also Meyer and Rowan, 1977; Oliver, 1991).

In the context of accounting standardization, personal legitimacy is concerned with perceptions of the personal characteristics of members of standard setting committees (Durocher $e t$ al., 2007). We expect that such perceptions will condition opinions of proposed financial reporting standards.

P 4.3: Individuals' perceptions of the value of a new financial reporting system are related to their perceptions of trust in the national standard setting team (i.e., personal legitimacy).

\section{Timing of implementation}

Carnall (2007) and Jarrar et al. (2007) examined the influence of the timing of implementation on individuals' reactions to change. Tyrrall et al. (2007) and Phan and Mascitelli (2014) examined these issues in the context of adoption of IFRS. Drawing on the results of these examinations, we 
expect that the perceived speed and timing of financial reporting reform is likely to affect the way individuals perceive its value.

P 4.4: Individuals' perceptions of the value of a new financial reporting system are related to their perceptions of the adequacy of the timing of the reform involved.

\section{Legal legitimacy}

Durocher et al. (2007) added another form of legitimacy to those identified by Suchman (1995): legal legitimacy. This argues that government and regulatory agencies support standardsetters and that this influences stakeholders' perceptions of the standard-setting process and of proposed standards. The importance of legal legitimacy is corroborated by Chand (2005). He highlighted the strategic importance of regulating financial reporting through legislation, so that the standard-setting process is independent and shielded from the unwarranted pressure of special interest groups. Campbell (2004) contended that the level of political support affects the approach to adoption, and that: “... the greater the level of general political support for the new principle or practice, the more likely it will be translated in toto and without modification" (p.81).

P 4.5: Individuals' perceptions of the value of a new financial reporting system are related to their views on the legal legitimacy of the accounting reform.

\section{Expected Contextual Variation}

In addition to the explanatory factors identified above, contextual variations associated with a particular stakeholder group will also influence the model. Thus, individuals' perceptions of the value of a new financial reporting system will differ across stakeholder groups - as depicted in Figure 2. Despite the relevance of all propositions to stakeholders in general, some propositions will have varying degrees of importance for specific stakeholder groups.

Our targeted stakeholders' groups are users (such as bank credit analysts, tax officials, managers and investors), preparers, and auditors. The most important propositions expected to explain users' perceptions are the resulting quality of financial reporting information (P2.1), the anticipated financial benefits (P3.5), and the perceived suitability of the IFRS model for the national environment (P3.1). Increased globalization pressures for international accounting convergence (P3.3) are expected to be particularly relevant for the investors' group. Figure 2 shows most of the propositions are important for preparers. This is not surprising, since this group is expected to be most affected by financial reporting change processes. For auditors, the technicalrelated propositions (P2.1 to 2.3 ) are not anticipated to be quite as relevant, since this group possesses enhanced knowledge of advanced financial reporting issues. We anticipate that auditors' perceptions will be influenced mainly by change process factors (P.4.1 to 4.5), and situational factors (P3.1 to 3.9) (such as the anticipated financial and professional benefits of adoption of an 
international financial reporting system) and change process factors (P4.1 to 4.5). Preparers and auditors are very involved and interested in the process of financial accounting reform - more so than users (who are more focused on the reform outcome). The expected contextual variations mentioned above need to be corroborated and further improved by future applications of this model.

Figure 2. Expected Contextual Variations in Relevance of Influential Factors for Individual Stakeholder Groups

\begin{tabular}{|c|c|c|}
\hline Individual factors & $\begin{array}{c}\text { Stakeholder Groups for whom } \\
\text { propositions have enhanced } \\
\text { relevance }\end{array}$ & \multirow{8}{*}{ PERCEIVED } \\
\hline (P 1.1) Age & Preparers, Auditors, Users & \\
\hline (P 1.2) Level of education & Preparers, Auditors, Users & \\
\hline (P 1.3) Level of experience & Preparers, Auditors & \\
\hline (P 1.4) Commitment to traditional accounting values & Preparers & \\
\hline (P 1.5) Disposition to change & Preparers, Auditors & \\
\hline (P 1.6) Personal impact of change & Preparers, Auditors & \\
\hline (P 1.7) Perceived usefulness of financial statements & Users & \\
\hline (P 1.8) Demands/ability fit & Preparers & \multirow[b]{2}{*}{$V A L U E$} \\
\hline (P 1.9) Interest/Functional group & Preparers & \\
\hline \multicolumn{2}{|l|}{ Technical Factors } & \multirow{4}{*}{$o f$} \\
\hline (P 2.1) Expected operational benefits & Users & \\
\hline (P 2.2) Complexity & Preparers & \\
\hline (P 2.3) Adoption costs & Preparers & \\
\hline \multicolumn{2}{|l|}{ Situational Factors } & \multirow{3}{*}{$N E W$} \\
\hline (P 3.1) Suitability for the national environment & Users & \\
\hline (P 3.2) Compatibility with the existing accounting culture & Preparers & \\
\hline (P 3.3) Suitability for context of globalization & Users (investors), Auditors & \multirow{3}{*}{$F I N A N C I A L$} \\
\hline (P 3.4) Suitability for the national business context & Preparers & \\
\hline (P 3.5) Anticipated contextual benefits & Users (investors), Auditors & \\
\hline & & REPORTING \\
\hline \multicolumn{2}{|l|}{ Change Process Factors } & \multirow{6}{*}{ SYSTEM } \\
\hline (P 4.1) Participation & Preparers, Auditors & \\
\hline$(\mathbf{P}$ 4.2) Communication & Preparers, Auditors & \\
\hline (P 4.3) Trust in the change agent & Preparers, Auditors & \\
\hline (P 4.4) Timing implementation issues & Preparers, Auditors & \\
\hline (P 4.5) Legal legitimacy & Preparers, Auditors & \\
\hline
\end{tabular}

\section{Conclusions}

The proposed model of factors affecting individuals' perceptions of financial reporting change (Figure 1) enhances ability to deduce the likely success or failure of a newly-adopted financial reporting regime (such as an IFRS-based system). The model offers beneficial prospects for the IASB, the EU, and national regulators planning to adopt IFRS or IFRS-based standards. It will help to identify particular issues and controversies that are likely to affect the implementation of IFRS or IFRS-based standards around the world.

The model proposes that success of a new financial reporting regime will be influenced strongly by the way individuals perceive the effects personally, and by a collection of technical, situational and change process factors. The theoretical propositions represent first approximations 
of the phenomenon under scrutiny. Nonetheless, the model contributes to the development of financial reporting by borrowing different approaches, lines of research and theories (hitherto unconnected), to investigate stakeholders' perceptions of financial reporting change.

The development of a comprehensive theoretical framework (integrating various streams of literature) contributes by identifying a wide range of factors that explain individuals' attitudes to change. This helps to make us better-placed to understand change in financial reporting. The focus on the often overlooked and under-researched micro-level of analysis (the influence of an individual's perception) helps to glean broader understandings of the institutionalisation process of financial reporting change. The insights offered by the proposed model should inform IFRS-based research by highlighting the wide array of change-related factors that affect the successful adoption of IFRS or IFRS-based standards nationally, and globally.

Future research that is directed to provide empirical support for the theorising underpinning the model will be beneficial. This will provide valuable information for national accounting standard-setters and other organisational leaders to help them devise appropriate strategies for coping with the perceived problems of implementing a new financial reporting system. Practical insights resulting from future implementation of this model might also highlight stakeholders' demand for changed social habits, behaviours and attitudes with regard to financial statements. Other useful and constructive insights derived from listening to stakeholders' voices seem likely to include the need for revised enforcement measures, enhanced disclosure requirements, adjustment of financial reporting-related tax rules, development of greater interaction and dialogue between all stakeholder groups (users, preparers and auditors), and adjustment of IASB standards to the needs of national and organizational environments. These measures have enhanced relevance in countries that have not embraced an IFRS philosophy: for example, where traditional and previous accounting values (conflicting with IFRS ideology) are deeply entrenched in stakeholders' accounting thought. By addressing stakeholders' concerns, and by solving some implementation problems, regulators will improve the likelihood that financial reporting reform will be accepted. Operationalisation of the proposed model holds the prospect of facilitating more effective implementation of new financial reporting systems.

Funding: This work was supported financially by the research unit on Governance, Competitiveness and Public Policy (project POCI-01-0145-FEDER-006939), through funds provided by COMPETE2020 - Programa Operacional Competitividade e Internacionalização (POCI); and Fundação para a Ciência e a Tecnologia. 


\section{References}

Abdullah, A., Khadaroo, I., \& Zhameshov, N. (2014). The relevance of international financial reporting standards to Kazakhstan: perception of auditors. International. Journal Accounting and Finance, 4(3), $305-322$.

Abu-Nassar, M., \& Rutherford, B.A. (1996). External Users of Financial Reports in Less Developed Countries: The Case of Jordan. The British Accounting Review, 28, 73-87.

Agarwal, R., \& Hoetker, G. (2007). A Faustian bargain? The growth of management and its relationship with related disciplines. Academy of Management Journal, 50(6), 1304-1322.

Albu, C.N. , Albu, N., \& Alexander, D. (2013b), The true and fair view concept in Romania: A case study of concept transferability, In C. N. Albu, \& R. V. Mustaţă (Ed.) Accounting in Central and Eastern Europe (Research in Accounting in Emerging Economies, Volume 13, pp. 61-90). Emerald Group Publishing Limited.

Albu, C.N., Albu, N., \& Alexander, D. (2014). When global accounting standards meet the local contextInsights from an emerging economy. Critical Perspectives on Accounting, 25, 489-510.

Albu, C.N., Albu, N., PaliPista, S.F., Selimoglu, S.K., Kovács, D.M., Lukács, J., Mohl, G., \& Mullevorá, L. (2013a). Implementation of IFRS for SMEs in Emerging Economies: Stakeholder Perceptions in the Czech Republic, Hungary, Romania and Turkey. Journal of International Financial Management \& Accounting, 24(2), 140-175.

Aljifri, K., \& Khasharmeh, H. (2006). An investigation into the suitability of the international accounting standards to the United Arab Emirates environment. International Business Review, 15, 505-526.

Alon, A. (2013). Complexity and Dual Institutionality: The Case of IFRS Adoption in Russia. Corporate Governance: An International Review, 21(1), 42-57.

Anderson, S.W. (1995). A framework for assessing cost management system changes: the case of activity based costing implementation at General Motors, 1986-1993. Journal of Management Accounting Research, 7, 1-51.

Armenakis, A.A., \& Bedeian, A.G. (1999). Organizational Change: A Review of Theory and Research in the 1990s. Journal of Management, 25(3), 293-315.

Armenakis, A.A., Harris, S. G., Cole, M.S., Fillmer, J. L., \& Self, D. R. (2007). A Top Management Team's Reactions to Organizational Transformation: The Diagnostic Benefits of Five Key Change Sentiments. Journal of Change Management, 7(3), 273 - 290.

Barth, M.E., Landsman, W.R., \& Lang, M. (2008). International Accounting Standards and Accounting Quality. Journal of Accounting Research, 46, 467 - 728.

Bem, D.J. (1967). Self-perception: An alternative interpretation of cognitive dissonance phenomena. Psychological review, 74(3), 183.

Blake, J., Fortes, H., Gowthorpe, C., \& Paananen, M. (1999). Implementing the EU Accounting Directives in Sweden - Practitioners' Views. The International Journal of Accounting, 34(3), 421-438.

Borbély, K., \& Evans, L. (2006). A Matter of Principle: Recent Developments in Hungarian Accounting Thought and Regulation. Accounting in Europe, 3(2), 135-168. 
Bordia, P., Hobman, E., Jones, E., Gallois, C., \& Callan, V.J. (2004). Uncertainty During Organizational Change: Types, Consequences, and Management Strategies. Journal of Business and Psychology, 18(4), 507-532.

Bruggemann, U., Hitz, J.-M., \& Sellhorn, T. (2013). Intended and unintended consequences of mandatory IFRS adoption: A review of extant evidence and suggestions for future research. European Accounting Review, 22(1), 1-37.

Burns, J., \& Baldvinsdottir, G. (2005). An institutional perspective of accountants' new roles - the interplay of contradictions and praxis. European Accounting Review, 14(4), 725 -757.

Caldwell, S.D., Herold, D.M., \& Fedor, D.B. (2004). Toward an Understanding of the Relationships Among Organizational Change, Individual Differences, and Changes in Person-Environment Fit: A Cross-Level Study. Journal of Applied Psychology, 89(5), 868-882.

Campbell, J.L. (2004). Institutional change and globalization. New Jersey: Princeton University Press.

Carnall, C.A. (2007). Managing Change in Organizations. Essex: Pearson Education.

Cassell, C.A., Giroux, G., Myers, L.A., \& Omer, T.C. (2013). The emergence of second- tier auditors in the US: evidence from investor perceptions of financial reporting credibility. Journal of Business Finance \& Accounting, 40(3-4), 350-372.

Chand, P. (2005). Impetus to the success of harmonization: the case of South Pacific Island nations. Critical Perspectives on Accounting, 16(3), 209-226.

Christensen, H.B., Lee, E., Walker, M., \& Zeng, C. (2015). Incentives or Standards: What Determines Accounting Quality Changes around IFRS Adoption? European Accounting Review, 24(1), 31-61.

Corbett, A., Cornelissen, J., Delios, A., \& Harley, B. (2014). Variety, novelty, and perceptions of scholarship in research on management and organizations: An appeal for ambidextrous scholarship. Journal of Management Studies, 51(1), 3-18.

Corley, K.G., \& Gioia, D.A. (2011). Building theory about theory building: what constitutes a theoretical contribution?. Academy of management review, 36(1), 12-32.

Covrig, V., Defond, M., \& Hung, M. (2007). Home Bias, Foreign Mutual Fund Holdings, and the Voluntary Adoption of International Accounting Standards. Journal of Accounting Research, 45(1), 41-50.

Cullen, K.L., Edwards, B.D., Casper, W.C., \& Gue, K.R. (2014). Employees’ Adaptability and Perceptions of Change-Related Uncertainty: Implications for Perceived Organizational Support, Job Satisfaction, and Performance. Journal of Business and Psychology, 9(2), 269-280.

Cunningham, G.B. (2006). The relationships among commitment to change, coping with change, and turnover intentions. European Journal of Work and Organizational Psychology, 15(1), 29-45.

Delone, W.H., \& McLean, E.R. (1992). Information Systems Success: The Quest for the Dependent Variable. Information Systems Research, 3(1), 60- 95.

Dibella, A.J. (2007). Critical Perceptions of Organisational Change. Journal of Change Management, 7(3), $231-242$.

DiMaggio, P.J., \& Powell, W.W. (1983). The iron cage revisited: institutional isomorphism and collective rationality in organization Welds. American Sociological Review, 48, 147-160.

Durocher, S., Fortin, A., \& Côté, L. (2007). User's participation in the accounting standards-setting process: A theory-building study. Accounting, Organizations and Society, 32, 29-59. 
Fedor, D.B., Caldwell, S., \& Herold, D.M. (2006). The effects of organizational changes on employee commitment: A Multilevel investigation. Personal Psychology, 59, 1-29.

Fox, A., Hannah, G., Helliar, C., \& Veneziani, M. (2013). The costs and benefits of IFRS implementation in the UK and Italy. Journal of Applied Accounting Research, 14(1), 86-101.

Genkova, P., \& Geher, C. (2016). Is Communication Always Helpful? - The Influence of Organizational Communication on Feelings of Uncertainty and Commitment of Employees during Change Management Processes. International Journal of Academic Research in Business and Social Sciences, 6(1), 55-66.

Georgalis, J., Samaratunge, R., Kimberley, N., \& Lu, Y. (2015). Change process characteristics and resistance to organisational change: The role of employee perceptions of justice. Australian Journal of Management , 40(1), 89-113.

Gibbins, M. (1984). Propositions about the psychology of professional judgment in public accounting. Journal of Accounting Research, 22(1), 103-125.

Glaum, M. (2000). Bridging the GAAP: the Changing attitude of German Managers towards AngloAmerican Accounting and Accounting Harmonization. Journal of International Financial Management and Accounting, 11(1), 23-47.

Goodman, J., \& Truss, C. (2004). The medium and the message: communicating effectively during a major change initiative. Journal of Change Management, 4(3), 217-228.

Gordon, J.R. (1993). A diagnostic approach to organizational behavior. Boston: Allyn and Bacon.

Guerreiro, M.S., Rodrigues, L.L., \& Craig, R. (2015). Institutional change of accounting systems: the adoption of a regime of adapted International Financial Reporting Standards. European Accounting Review, 24(2), 379-409.

Guerreiro, M.S., Rodrigues, L.R. \& Craig, R. (2012). Voluntary adoption of International Financial Reporting Standards by large unlisted companies in Portugal - institutional logics and strategic responses. Accounting, Organizations \& Society, 37, 482-499.

Halbouni, S.S., \& Nour, M.A. (2014). An empirical study of the drivers of management accounting innovation: a UAE perspective. International Journal of Managerial and Financial Accounting, 6(1), $60-86$.

Hambrick, D.C. (2007). The field of management's devotion to theory: Too much of a good thing?. Academy of Management Journal, 50(6), 1346-1352.

Hamid, S.A., Craig, R., \& Clarke, F.L. (1993). Religion: A confounding cultural element in the international harmonization of accounting? Abacus, 29, 131-48.

Heggestad, E.D., \& Kanfer, R. (2000). Individual differences in trait motivation: development of the Motivational Trait Questionnaire. International Journal of Educational Research, 33, 751-776.

Hicks, J.O. (1978). An Examination of Accounting Interest Groups’ Differential Perceptions of Innovations. Accounting Review, 53(2), 371-388.

Ho, S.S., \& Wong, K.S. (2001). A Study of Corporate Disclosure Practice and Effectiveness in Hong Kong. Journal of International Financial Management and Accounting, 12(1), 75-102.

Ho, S.S., \& Wong, K.S. (2003). Preparer's perceptions of corporate reporting and disclosures. International Journal of Disclosure and Governance, 1(1), 71-81. 
Holt, D.T., Armenakis, A.A., Field, H.S., \& Harris, S.G. (2007). Readiness for Organizational Change: The Systematic Development of a Scale. Journal of Applied Behavioral Science, 43(2), 232-255.

Hope, O., Jin, J.A., \& Kang, T. (2006). Empirical Evidence of Jurisdictions that Adopt IFRS. Journal of International Accounting Research, 5(2), 1-20.

Humphrey, C., \& Scapens, R.W. (1996). Theories and case studies of organizational accounting practices.

Igbaria, M., Guimaraes, T., \& Davis, G.B. (1995) Testing the determinants of microcomputer usage via a structural equation model. Journal of Management Information Systems, 11(4), 87 -114.

Irvine, H. (2008). The global institutionalization of financial reporting: The case of the United Arab Emirates. Accounting Forum, 32, 125- 142.

Jarrar, N.S., Smith, M., \& Dolley. C. (2007). Perceptions of preparers and users to accounting change: a case study in an Australian university. Managerial Auditing Journal, 22(1), 80-94.

Jaruga, A., Fijalkowska, J., Jaruga-Baranowska, M., \& Frendzel, M. (2007). The Impact of IAS/IFRS on Polish Accounting Regulations and their Practical Implementation in Poland. Accounting in Europe, 4(1), 67-78.

Jermakowicz, E.K. (2004). Effects of Adoption of International Financial Reporting Standards in Belgium. Accounting in Europe, 1, 51-70.

Jermakowicz, E.K., \& Gornik-Tomaszewski, S. (2006). Implementing IFRS from the perspective of EU publicly traded companies. Journal of International Accounting, Auditing and Taxation, 15, 170-196.

Jermias, J. (2001). Cognitive dissonance and resistance to change: the influence of commitment confirmation and feedback on judgment usefulness of accounting systems. Accounting, Organizations and Society, 26, 141-160.

Jimmieson, N.L., White, K.M., \& Zajdlewicz, L. (2009). Psychosocial Predictors of Intentions to Engage in Change Supportive Behaviors in an Organizational Context. Journal of Change Management, 9(3), 233 250.

Jones, T., \& Luther, R. (2005). Anticipating the impact of IFRS on the Management of German Manufacturing Companies: Some Observations from a British Perspective. Accounting in Europe, 2 , 165-193.

Joos, P.M. \& Leung, E. (2013). Investor Perceptions of Potential IFRS Adoption in the United States. Accounting Review, 88(2),577-609.

Joshi, P. L., \& Al-Basteki, H. (1999). Development of Accounting Standards and Adoption of IASs: Perceptions of Accountants from a Developing Country. Asian Review of Accounting, 7(2), 96- 117.

Joshi, P.L., \& Ramadhan, S. (2002). The adoption of international accounting standards by small and closely held companies: evidence from Bahrain. The International Journal of Accounting, 37, 429-440.

Joshi, P.L., Brenser, W.G., \& Al Ajmi, J. (2008). Perceptions of Accounting Professionals in the Adoption and Implementation of a Single Set of Global Accounting Standards: Evidence from Bahrain. Advances in Accounting, incorporating Advances in International Accounting, 24, 41- 48.

Judge, T.A., Thoresen, C.J., Pucik, V., \& Welbourne, T.M. (1999). Managerial coping with organizational change: A dispositional perspective. Journal of Applied Psychology, 84, 107 - 122.

Kanellou, A. \& Spathis, C. (2013). Accounting benefits and satisfaction in an ERP environment. International Journal of Accounting Information Systems, 12, 209-234. 
Kanfer, R., \& Ackerman, P.L. (2004). Aging, Adult Development, and Work Motivation Source. Academy of Management Review, 29(3), 440-458.

Kenworthy, T.P., \& Verbeke, A. (2015). The future of strategic management research: Assessing the quality of theory borrowing. European Management Journal, 33(3), 179-190.

Kiliç, M., Atamanc, B., \& Uyar, A. (2014). Preparedness for and perception of IFRS. Accounting and Management Information Systems, 13(3), 492.

Kirk, N. (2006). Perceptions of the True and Fair View Concept: An Empirical Investigation. Abacus, 42(2), 205-235.

Kılı̧, M., Uyar, A., \& Ataman, B. (2014). Preparedness for and perception of IFRS for SMEs: evidence from Turkey. Accounting and Management Information Systems, 13(3),492-519.

Laughlin, R. (1995). Empirical research in accounting: alternative approaches and a case for "middle-range" thinking. Accounting, Auditing \& Accountability Journal, 8(1), 63-87.

Lin, Z.J., Chen, F., \& Tang, Q. (2001). An empirical evaluation of the new system business in China. Journal of International Accounting, Auditing and Taxation, 10, 23-49.

Marinova, S.V., Peng, C., Lorinkova, N., Dyne, L.V., \& Chiaburu, D. (2015). Change-oriented behavior: A meta-analysis of individual and job design predictors. Journal of Vocational Behavior, 88, 104-120.

McEnroe, J., \& Sullivan, M. (2006). Individual investors' attitudes towards listing requirements for foreign entities on U.S. stock exchanges and the promulgation of international accounting standards. Journal of International Accounting, Auditing and Taxation, 15, 215-225.

McGowan, A.S. (1998). Perceived Benefits of ABCM Implementation. Accounting Horizons, 12(1), 31-50.

McKinnon, S.M. (1984). A Cost-Benefit Study of Disclosure Requirements for Multinational Corporations. Journal of Business Finance \& Accounting, 11(4), 451-468.

McLaren, J., Appleyard, T., \& Mitchell, F. (2016). The rise and fall of management accounting systems: A case study investigation of EVA. The British Accounting Review, in press, 1-18.

McNally, G.M., Eng, L.H., \& Hasseldine, C.R. (1982). Corporate Financial Reporting in New Zealand: An Analysis of User Preferences, Corporate Characteristics and Disclosure Practices for Discretionary Information. Accounting and Business Research, 13, 11-20.

Meglino, B.M., \& Korsgaard, M.A. (2004). Considering Rational Self-Interest as a Disposition: Organizational Implications of Other Orientation. Journal of Applied Psychology, 89(6), 946-959.

Meyer, J.W., \& Rowan, B. (1977) [1991]. Institutionalized organizations: formal structure as myth and ceremony. American Journal of Sociology, 83(2), 340-363. Reprinted in W.W. Powell \& P.J. DiMaggio (Eds.), The new institutionalism in organizational analysis (pp. 41-62). Chicago: University of Chicago Press.

Miller, P. (1994), “Accounting as social and institutional practice: an introduction”, in Hopwood, A. and Miller, P. (Eds), Accounting as Social and Institutional Practice, Cambridge: Cambridge University Press.

Miller, P. \& O' Leary, T. (1994). Accounting, 'Economic Citizenship', and the Spatial Reordering of Manufacture, Accounting Organizations and Society, 19(1), 15-43.

Miller, P., \& O' Leary, T. (1987). Accounting and the construction of the governable person. Accounting, Organizations and Society, 12(3), 235-265. 
Mir, M.Z., \& Rahaman, A.S. (2005). The adoption of international accounting standards in Bangladesh: An exploration of rationale and process. Accounting, Auditing \& Accountability Journal, 18(6), 816-841.

Mirshekary, S., \& Saudagaran, S.M. (2005). Perceptions and characteristics of financial statement users in developing countries: Evidence from Iran. Journal of International Accounting, Auditing and Taxation, $14,33-54$.

Morris, R.D., Gray, S. J., Pickering, J. \& Aisbitt, S. (2014). Preparers' Perceptions of the Costs and Benefits of IFRS: Evidence from Australia’s Implementation Experience. Accounting Horizons, 28 (1), 143-173.

Naser, K., \& Nuseibeh, R. (2003a). User's perception of corporate reporting: evidence from Saudi Arabia. British Accounting Review, 35, 129-153.

Naser, K., \& Nuseibeh, R. (2003b). Quality of financial reporting: evidence from the listed Saudi nonfinancial companies. International Journal of Accounting, 38, 41-69.

Naser, K., Al-Khyal, T., Nuseibeh, R., \& Al-Tweel, I. (2005). Users' Opinions about different aspects of Accounting Harmonization: Evidence from the Gulf Co-Operational Council (GCC). International Journal of Commerce \& Management, 15(3/4), 272-299.

Naser, K., Nuseibeh, R., \& Al-Hussaini, A. (2003). Users' perception of various aspects of Kuwait corporate reporting. Managerial Auditing Journal, 18(6/7), 599-617.

Neves, P. (2009). Readiness for Change: Contributions for Employee's Level of Individual Change and Turnover Intentions. Journal of Change Management, 9(2), 215 - 231.

Oliver, C. (1991). Strategic Responses to Institutional Processes. Academy of Management Review, 16(1), 145-179.

Oreg, S. (2006). Personality, context, and resistance to organizational change. European Journal of Work and Organizational Psychology, 15(1), 73 - 101.

Oswick, C., Fleming, P., \& Hanlon, G. (2011). From borrowing to blending: Rethinking the process of organizational theory building. Academy of Management Review, 36(2), 318-337.

Pfeffer, J., \& Salancik, G. (1978). External Control of Organizations: A Resource Dependence Perspective. New York: Harper and Row.

Phan, D.C., \& Mascitelli, B. (2014). Optimal approach and timeline for IFRS adoption in Vietnam: Perceptions from accounting professionals. Research in Accounting Regulation, 26, 222-229.

Potter, B.N. (2002). Financial Accounting Reforms in the Australian Public Sector: An Episode in Institutional Thinking. Accounting, Auditing and Accountability Journal, 15(1), 69-93.

Potter, B.N. (2005). Accounting as a Social and Institutional Practice: Perspectives to Enrich our Understanding of Accounting Change. Abacus, 41(3), 265-289.

Power, M. (1992). The politics of brand accounting in the United Kingdom. The European Accounting Review, 1(1), 39-68.

Power, M. (1997). Expertise and the Construction of Relevance: Accountants and Environmental Audit. Accounting, Organizations and Society, 22(2), 123-147.

Quagli A., \& Paoloni, P. (2012). How is the IFRS for SME accepted in the European context? An analysis of the homogeneity among European countries, users and preparers in the European commission questionnaire. Advances in Accounting, incorporating Advances in International Accounting, 28, 147156. 
Rafferty, A.E., Jimmieson, N.L., \& Armenakis, A.A. (2013). Change Readiness: A Multilevel Review. Journal of Management, 39(1), 110-135.

Rees, N.A., \& Chandler, R.A. (2004). Accounting Harmonisation through the Eyes of UK Finance Directors. Working Paper, Cardiff, Wales: University of Cardiff, Cardiff Business School.

Roberts, C.B., \& Salter, S.B. (1999). Attitudes towards Uniform Accounting: Cultural or Economic Phenomena?. Journal of International Financial Management and Accounting, 10(2), 121-142.

Rodrigues, L.L., \& Craig, R. (2007). Assessing international accounting harmonization using Hegelian dialectic, isomorphism and Foucault. Critical Perspectives on Accounting, 18, 739-757.

Rose, N., \& Miller, P. (1992), Political Power Beyond the State: The Problematics of Government. British Journal of Sociology, 43(2), 172-205.

Scapens, R.W., \& Roberts, J. (1993). Accounting and control: a case study of resistance to accounting change. Management Accounting Research, 4(1), 1-32.

Schneider, D.K., \& Gordon, S. (1994). On the Credibility of GAAP: Do Preparers, Auditors and Users see eye to eye?. Journal of Applied Business Research, 10(4), 77-88.

Scott, W.R. (2010). Reflections: The Past and Future of Research on Institutions and Institutional Change. Journal of Change Management, 10(1), 5-21.

Sekuller, R., \& Blake, R. (1994). Perception. New York: McGraw-Hill.

Self, D.R., Armenakis, A.A., \& Schraeder, M. (2007). Organizational Change Content, Process, and Context: A Simultaneous Analysis of Employee Reactions. Journal of Change Management, 7(2), 211-229.

Seo, M.G., \& Creed, W.E. (2002). Institutional contradictions, praxis and institutional change: a dialectical perspective. Academy of Management Review, 27(2), 222-247.

Shafir, E., \& LeBoeuf, R.A. (2002). Rationality. Annual Review Psychology, 53, 491-517.

Shields, M.D. (1995). An Empirical Analysis of Firms' Implementation Experiences with Activity-Based Costing. Journal of Management Accounting Research, 7, 148-166.

Sinatra, G.M. (2002). Motivational, Social, and Contextual Aspects of Conceptual Change: A Commentary. In M. Limón \& L. Mason (Eds.), Reconsidering Conceptual Change. Issues in Theory and Practice (pp. 187-197). Boston MA: Kluwer.

Son, D.D., Marriott, N., \& Marriott, P. (2006). Users' perceptions and uses of financial reports of small and medium companies (SMCs) in transactional economies: Qualitative evidence from Vietnam. Qualitative Research in Accounting \& Management, 3(3), 218-235.

Sucher, P., \& Jindrichovska, I. (2004). Implementing IFRS: A Case Study of Czech Republic. Accounting in Europe, 1, 109-141.

Suchman, M.C. (1995). Managing legitimacy: strategic and institutional approaches. Academy of Management Review, 20(3), 571-610.

Turel, O., Serenko, A., \& Bontis, N. (2007). User acceptance of wireless short messaging services: Deconstructing perceived value. Information \& Management, 44(1), 63-73.

Tyrrall, D., Woodward, D., \& Rakhimbekova, A. (2007). The relevance of International Financial Reporting Standards to a developing country: Evidence from Kazakhstan. International Journal of Accounting, 42(1), 82-110. 
Uyar, A. \& Güngörmüş A.H. (2013). Perceptions and knowledge of accounting professionals on IFRS for SMEs: Evidence from Turkey. Research in Accounting Regulation. 25, 77-87.

Vellam, I. (2004). Implementation of International Accounting Standards in Poland: Can True Convergence be Achieved in Practice? Accounting in Europe, 1(1), 143-167.

Vroom, V.H. (1995). Work and Motivation. San Francisco: Jossey-Bass.

Walker, H.J., Armenakis, A.A., \& Bernerth, J.B. (2007). Factors influencing organizational change efforts: An integrative investigation of change content, context, process and individual differences. Journal of Organizational Change Management, 20(6), 761-773.

Walker, R.G. (1987). Australia's ASRB. A Case Study of Political Activity and Regulatory 'Capture'. Accounting and Business Research, 17(67), 269 - 286.

Walker, R.G., \& Robinson, S.P. (1994). Related Party Transactions: A Study of Inter-Organizational Conflict Over the 'Development' of Disclosure Rules. Abacus, 30(1), 18-43.

Watty, K., \& Carlson, P. (1998). Demand for International Accounting Standards: A Customer Quality Perspective. Advances in International Accounting, 11, 133-154.

Weber, M. (1978). Economy and society. Berkeley: University of California Press.

Whetten, D.A. (2009). An examination of the interface between context and theory applied to the study of Chinese organizations. Management and Organization Review, 5(1), 29-55.

Xiao, J.Z., Weetman, P., \& Sun, M. (2004). Political Influence and Coexistence of a Uniform Accounting System and Accounting Standards: Recent Developments in China. Abacus, 40(2), 193-218.

Young, J.J. (1996). Institutional Thinking: The Case of Financial Instruments. Accounting, Organizations and Society, 21(5), 487-512.

Young, J.J. (2003). Constructing, Persuading and Silencing: The Rhetoric of Accounting Standards. Accounting, Organizations and Society, 28(6), 621-638.

Zmud, E.W. (1979). Individual Differences and MIS Success: A Review of the Empirical Literature. Management Science, 25(10), 966-979. 